\title{
SANKSI BAGI NOTARIS YANG MEMPROMOSIKAN JABATANNYA PADA SOSIAL MEDIA
}

\author{
Meishell Njoto ${ }^{1}$ \\ Email: mshell.njoto@gmail.com
}

\begin{abstract}
Notary plays an important role in making authentic deed in Indonesia. Notaries are often referred to occupying honorary positions as general or state officials. As the holder of an honorary position trusted by the public to make an authentic deed, the Notary must comply with the applicable laws and the Code of Ethics. Obligations and prohibitions of Notaries have clearly been regulated in UUJN and Notary Ethics Code, but that does not mean there are no Notaries who violate these rules. In order to find out what the legal consequences of a notary who violated social media promotion, the authors conducted this research. The research method used in this study is normative legal research. Normative legal research is legal research conducted by examining materials derived from various laws and regulations and other materials from various literatures. Which means this research examines secondary data material or does a literature review. The approach used in this study is the statutory approach and the conceptual approach. The result of this research is the prohibition on promotion through social media which actually has been regulated in various rules regarding notaries along with the legal consequences if the Notary Public violates these rules.
\end{abstract}

Key-word: Notary, Social Media

\section{Pendahuluan}

Globalisasi mempengaruhi berbagai aspek kehidupan masyarakat khususnya dalam hal teknologi dan informasi. Dengan adanya globalisasi, masyarakat dituntut untuk selalu dinamis. Begitu pula dengan pemerintah dalam membentuk payung hukum. Hukum harus berkembang mengikuti perkembangan yang ada di masyarakat untuk mewujudkan kepastian hukum.

Peranan hukum dalam mengatur kehidupan masyarakat sudah dikenal sejak masyarakat mengenal hukum itu sendiri, sebab hukum itu dibuat untuk mengatur kehidupan manusia sebagai makhluk sosial. Hubungan antara masyarakat dan hukum

\footnotetext{
${ }^{1}$ Universitas Surabaya
} 


\section{Jurnal Panorama Hukum}

diungkapkan dengan sebuah adagium yang sangat terkenal dalam ilmu hukum yaitu : ubi societas ibi ius (dimana ada masyarakat di sana ada hukum). ${ }^{2}$

Masyarakat sebagai makhluk sosial tentunya dalam kehidupan sehari-hari akan melakukan interaksi sosial. Tidak jarang interaksi sosial itu berupa hubungan hukum yang akan melahirkan perbuatan hukum, dan akan menimbulkan akibat hukum. Seringkali hubungan hukum memerlukan alat bukti berupa akta otentik sebagai alat bukti yang sempurna. Salah satu pejabat yang berwenang membuat akta otentik adalah Notaris.

Notaris adalah Pejabat Negara yang bertugas untuk melayani masyarakat. Notaris disebut pejabat umum karena Notaris diangkat dan diberhentikan oleh negara. ${ }^{3}$ Peran Notaris dalam sektor pelayanan jasa adalah sebagai pejabat yang diberi wewenang oleh negara untuk melayani masyarakat dalam bidang perdata khususnya pembuatan akta otentik $^{4}$ Sebagai pejabat yang baik dan berfungsi melayani masyarakat, notaris selayaknya tidak mencari keuntungan-keuntungan demi kepentingan pribadinya termasuk diantaranya mempromosikan jasanya.

Karena memegang jabatan yang sangat penting yaitu pejabat negara, dalam menjalankan jabatannya Notaris harus tunduk kepada perundang-undangan yang berlaku secara umum di Indonesia khususnya UUJN dan Kode Etik Notaris. Selain itu Notaris juga tunduk kepada organisasi profesi Notaris yang bernama Ikatan Notaris Indonesia (INI). Kode Etik Notaris ditentukan oleh INI.

Kode etik yang ditetapkan di Banten, pada tanggal 29-30 Mei 2015 yang sebelumnya berlaku Kode Etik Notaris yang ditetapkan pada kongres INI di Bandung tanggal 28 Januari 2005 tersebut memuat kewajiban, larangan dan pengecualian bagi notaris dalam pelaksanaan jabatannya. Notaris dapat dikenakan sanksi apabila terbukti telah melakukan pelanggaran atas ketentuan-ketentuan yang dimuat dalam Kode Etik Notaris. 5

\footnotetext{
${ }^{2}$ Satjipto Raharjo, (1983), Masalah Penegakan Hukum, Sinar Baru, Bandung, hlm 127.

${ }^{3}$ Stephanie, Peranan Ikatan Notaris Indonesia (I.N.I) Terhadap Pengawasan Notaris Dalam Pelaksanaan Tugas Jabatan Notaris Di Provinsi Dki Jakarta, hlm 2.

${ }^{4}$ Ferdiansyah Putra, Perlindungan Hukum Terhadap Para Pihak Yang Dirugikan Atas Penyuluhan Hukum Oleh Notaris, hlm 27

${ }^{5}$ Riyan Saputra, Penegakan Hukum Terhadap Notaris Yang Mempromosikan Diri Melalui Media Sosial, hlm 4.
} 


\section{Jurnal Panorama Hukum}

Fungsi kode etik bersifat ganda yaitu: ${ }^{6}$

1. Mengontrol perilaku anggota profesi agar tidak terjadi penyalahgunaan pengetahuan/keunggulan yang dimiliki profesi dimaksud

2. Kode etik berfungsi untuk menjaga martabat profesi.

Sejalan dengan globalisasi khususnya dalam dunia teknologi dan informasi tentu juga memberikan dampak yang besar bagi kelangsungan profesi Notaris di Indonesia. Perkembangan teknologi dan informasi dapat meningkatkan efektivitas dan efisiensi pelayanan Notaris kepada masyarakat di Indonesia. Namun tidak bisa dipungkiri bahwa globalisasi dapat menimbulkan dampak negatif terhadap profesi Notaris dalam menjalankan jabatannya. Dampak negatif tersebut bisa timbul apabila Notaris kurang menguasai Undang-Undang Jabatannya maupun Kode Etik Notaris.

\section{Pembahasan}

\section{Sanksi bagi Notaris yang mempromosikan jabatannya melalui sosial media}

Pasal 6 angka 1 dan 2 Kode Etik Notaris ${ }^{7}$

1. Sanksi yang dapat dikenakan terhadap anggota yang melakukan pelanggaran Kode Etik dapat berupa :
a. teguran;
b. Peringatan;
c. schorsing (pemecatan sementara) dari keanggotaan Perkumpulan;
d. onzetting (pemecatan) dari keanggotaan Perkumpulan;
e. pemberhentian dengan tidak hormat dari kenaggotaan Perkumpulan.

2. Penjatuhan sanksi - sanksi sebagaimana terurai di atas terhadap anggota yang melanggar Kode Etik disesuaikan dengan kwantitas dan kwalitas pelanggaran yang dilakukan anggota tersebut.

\section{Kewajiban dan larangan bagi Notaris}

Notaris sebagai pemegang jabatan penting memiliki kewajiban yang harus dipatuhi dan larangan yang tidak boleh dilakukan dalam menjalankan tugas jabatannya. Kewajiban

\footnotetext{
${ }^{6}$ Yovita A. Mangesti dan Bernard L. Tanya, (2014), Moralitas Hukum, Yogyakarta, Genta Publishing, hlm 104.

${ }^{7}$ Kode Etik Notaris (Ikatan Notaris Indonesia / I.N.I), pasal 6 (1) dan pasal 6(2).
} 


\section{Jurnal Panorama Hukum}

dan larangan notaris diatur dalam Pasal 16-17 UUJN dan pasal 3-4 Kode Etik Notaris yang berbunyi sebagai berikut :

Pasal 16 (1) UUJN "Dalam menjalankan jabatannya, notaris wajib :

a. bertindak amanah, jujur, saksama, mandiri, tidak berpihak, dan menjaga kepentingan pihak yang terkait dalam perbuatan hukum;

b. membuat Akta dalam bentuk Minuta Akta dan menyimpannya sebagai bagian dari Protokol Notaris;

c. melekatkan surat dan dokumen serta sidik jari penghadap pada Minuta Akta;

d. mengeluarkan Grosse Akta, Salinan Akta, atau Kutipan Akta berdasarkan Minuta Akta;

e. memberikan pelayanan sesuai dengan ketentuan dalam Undang-Undang ini, kecuali ada alasan untuk menolaknya;

f. merahasiakan segala sesuatu mengenai Akta yang dibuatnya dan segala keterangan yang diperoleh guna pembuatan Akta sesuai dengan sumpah/janji jabatan, kecuali undang-undang menentukan lain;

g. menjilid Akta yang dibuatnya dalam 1 (satu) bulan menjadi buku yang memuat tidak lebih dari 50 (lima puluh) Akta, dan jika jumlah Akta tidak dapat dimuat dalam satu buku, Akta tersebut dapat dijilid menjadi lebih dari satu buku, dan mencatat jumlah Minuta Akta, bulan, dan tahun pembuatannya pada sampul setiap buku;

h. membuat daftar dari Akta protes terhadap tidak dibayar atau tidak diterimanya surat berharga;

i. membuat daftar Akta yang berkenaan dengan wasiat menurut urutan waktu pembuatan Akta setiap bulan;

j. mengirimkan daftar Akta sebagaimana dimaksud dalam huruf i atau daftar nihil yang berkenaan dengan wasiat ke pusat daftar wasiat pada kementerian yang menyelenggarakan urusan pemerintahan di bidang hukum dalam waktu 5 (lima) hari pada minggu pertama setiap bulan berikutnya;

k. mencatat dalam repertorium tanggal pengiriman daftar wasiat pada setiap akhir bulan; 
1. mempunyai cap atau stempel yang memuat lambang negara Republik Indonesia dan pada ruang yang melingkarinya dituliskan nama, jabatan, dan tempat kedudukan yang bersangkutan;

m. membacakan Akta di hadapan penghadap dengan dihadiri oleh paling sedikit 2 (dua) orang saksi, atau 4 (empat) orang saksi khusus untuk pembuatan Akta wasiat di bawah tangan, dan ditandatangani pada saat itu juga oleh penghadap, saksi, dan Notaris; dan

n. menerima magang calon Notaris."

Pasal 17 ayat (1) UUJN “(1) Notaris dilarang:

a. menjalankan jabatan di luar wilayah jabatannya;

b. meninggalkan wilayah jabatannya lebih dari 7 (tujuh) hari kerja berturut-turut tanpa alasan yang sah;

c. merangkap sebagai pegawai negeri;

d. merangkap jabatan sebagai pejabat negara;

e. merangkap jabatan sebagai advokat;

f. merangkap jabatan sebagai pemimpin atau pegawai badan usaha milik negara, badan usaha milik daerah atau badan usaha swasta;

g. merangkap jabatan sebagai Pejabat Pembuat Akta Tanah dan/atau Pejabat Lelang Kelas II di luar tempat kedudukan Notaris;

h. menjadi Notaris Pengganti; atau

i. melakukan pekerjaan lain yang bertentangan dengan norma agama, kesusilaan, atau kepatutan yang dapat mempengaruhi kehormatan dan martabat jabatan Notaris."

Pasal 17 ayat (2) UUJN "Notaris yang melanggar ketentuan sebagaimana dimaksud pada ayat (1) dapat dikenai sanksi berupa :
a. peringatan tertulis;
b. pemberhentian sementara;
c. pemberhentian dengan hormat; atau
d. pemberhentian dengan tidak hormat."

Pasal 3 Kode Etik Notaris "Notaris dan orang lain yang memangku dan menjalankan jabatan Notaris wajib : 


\section{Jurnal Panorama Hukum

1. Memiliki moral, akhlak serta kepribadian yang baik.

2. Menghormati dan menjunjung tinggi harkat dan martabat jabatan Notaris.

3. Menjaga dan membela kehormatan Perkumpulan.

4. Bertindak jujur, mandiri, tidak berpihak, penuh rasa tanggung jawab, berdasarkan peraturan perundang-undangan dan isi sumpah jabatan Notaris.

5. Meningkatkan ilmu pengetahuan yang telah dimiliki tidak terbatas pada ilmu pengetahuan hukum dan kenotariatan.

6. Mengutamakan pengabdian kepada kepentingan masyarakat dan Negara.

7. Memberikan jasa pembuatan akta dan jasa keNotarisan lainnya untuk masyarakat yang tidak mampu tanpa memungut honorarium.

8. Menetapkan satu kantor di tempat kedudukan dan kantor tersebut merupakan satusatunya kantor bagi Notaris yang bersangkutan dalam melaksanakan tugas jabatan sehari-hari.

9. Memasang 1 (satu) buah papan nama di depan / di lingkungan kantornya dengan pilihan ukuran yaitu $100 \mathrm{~cm}$ x $40 \mathrm{~cm}, 150 \mathrm{~cm}$ x $60 \mathrm{~cm}$ atau $200 \mathrm{~cm}$ x $80 \mathrm{~cm}$, yang memuat :

a. Nama lengkap dan gelar yang sah;

b. Tanggal dan nomor Surat Keputusan pengangkatan yang terakhir sebagai Notaris.

c. Tempat kedudukan;

d. Alamat kantor dan nomor telepon/fax. Dasar papan nama berwarna putih dengan huruf berwarna hitam dan tulisan di papan nama harus ielas dan mudah dibaca. Kecuali di lingkungan kantor tersebut tidak dimungkinkan untuk pemasangan papan nama dimaksud.

10. Hadir, mengikuti dan berpartisipasi aktif dalam setiap kegiatan yang diselenggarakan oleh Perkumpulan; menghormati, mematuhi, melaksanakan setiap dan seluruh keputusan Perkumpulan.

11. Membayar uang iuran Perkumpulan secara tertib.

12. Membayar uang duka untuk membantu ahli waris teman sejawat yang meninggal dunia.

13. Melaksanakan dan mematuhi semua ketentuan tentang honorarium ditetapkan Perkumpulan. 


\section{Jurnal Panorama Hukum}

14. Menjalankan jabatan Notaris terutama dalam pembuatan, pembacaan dan penandatanganan akta dilakukan di kantornya, kecuali alasan-alasan yang sah.

15. Menciptakan suasana kekeluargaan dan kebersamaan dalam melaksanakan tugas jabatan dan kegiatan sehari-hari serta saling memperlakukan rekan sejawat secara baik, saling menghormati, saling menghargai, saling membantu serta selalu berusaha menjalin komunikasi dan tali silaturahmi.

16. Memperlakukan setiap klien yang datang dengan baik, tidak membedakan status ekonomi dan/atau status sosialnya.

17. Melakukan perbuatan-perbuatan yang secara umum disebut sebagai kewajiban untuk ditaati dan dilaksanakan antara lain namun tidak terbatas pada ketentuan yang tercantum dalam :

a. UU Nomor 30 Tahun 2004 tentang Jabatan Notaris;

b. Penjelasan Pasal 19 ayat (2) UU Nomor 30 Tahun 2004 tentang Jabatan Notaris;

c. Isi Sumpah Jabatan Notaris;

d. Anggaran Dasar dan Anggaran Rumah Tangga Ikatan Notaris Indonesia."

Pasal 4 Kode Etik Notaris "Notaris dan orang lain yang memangku clan menjalankan jabatan. Notaris dilarang :

1. Mempunyai lebih dari 1 (satu) kantor, baik kantor cabang ataupun kantor perwakilan.

2. Memasang pagan Hama dan/atau tulisan yang berbunyi "Notaris/ Kantor Notaris" di luar lingkungan kantor.

3. Melakukan publikasi atau promosi diri, baik sendiri maupun secara bersamasama, dengan mencantumkan nama dan jabatannya, menggunakan sarana media cetak dan/atau elektronik, dalam bentuk
a. Iklan;
b. Ucapan selamat;
c. Ucapan belasungkawa;
d. Ucapan terima kasih;
e. Kegiatan pemasaran; 


\section{Jurnal Panorama Hukum}

f. Kegiatan sponsor, baik dalam bidang sosial, keagamaan, maupun olahraga;

4. Bekerja sama dengan Biro jasa/orang/Badan Hukum yang pada hakekatnya bertindak sebagai perantara untuk mencari atau mendapatkan klien.

5. Menandatangani akta yang proses pembuatan minutanya telah dipersiapkan oleh pihak lain.

6. Mengirimkan minuta kepada klien untuk ditanda tangani.

7. Berusaha atau berupaya dengan jalan apapun, agar seseorang berpindah dari Notaris lain kepadanya, baik upaya itu ditujukan langsung kepada klien yang bersangkutan maupun melalui perantara orang lain.

8. Melakukan pemaksaan kepada klien dengan cara menahan dokumen-dokumen yang telah diserahkan dan/atau melakukan tekanan psikologis dengan maksud agar klien tersebut tetap membuat akta padanya.

9. Melakukan usaha-usaha, baik langsung maupun tidak langsung yang menjurus ke arah timbulnya persaingan yang tidak sehat dengan sesama rekan Notaris.

10. Menetapkan honorarium yang harus dibayar oleh klien dalam jumlah yang lebih rendah dari honorarium yang telah ditetapkan Perkumpulan.

11. Mempekerjakan dengan sengaja orang yang masih berstatus karyawan kantor Notaris lain tanpa persetujuan terlebih dahulu dari Notaris yang bersangkutan.

12. Menjelekkan dan/atau mempersalahkan rekan Notaris atau akta yang dibuat olehnya. Dalam hal seorang Notaris menghadapi dan/atau menemukan suatu akta yang dibuat oleh rekan sejawat yang ternyata didalamnya terdapat kesalahankesalahan yang serius dan/atau membahayakan klien, make Notaris tersebut wajib memberitahukan kepada rekan sejawat yang bersangkutan etas kesalahan yang dibuatnya dengan cara yang tidak bersifat menggurui, melainkan untuk mencegah timbulnya hal-hal yang tidak diinginkan terhadap klien yang bersangkutan ataupun rekan sejawat tersebut.

13. Membentuk kelompok sesama rekan sejawat yang bersifat ekslusif dengan tujuan untuk melayani kepentingan suatu instansi atau lembaga, apalagi menutup kemungkinan bagi Notaris lain untuk berpartisipasi.

14. Menggunakan dan mencantumkan gelar yang tidak sesuai dengan peraturan perundangundangan yang berlaku. 


\section{Jurnal Panorama Hukum}

15. Melakukan perbuatan-perbuatan lain yang secara umum disebut sebagai pelanggaran terhadap Kode Etik Notaris, antara lain namun tidak terbatas pada pelanggaran-pelanggaran terhadap :

a. Ketentuan-ketentuan dalam Undang-undang Nomor 30 Tahun 2004 tentang Jabatan Notaris;

b. Penjelasan pasal 19 ayat (2) Undang-undang Nomor 30 tahun 2004 tentang Jabatan Notaris;

c. Isi sumpah jabatan Notaris;

d. Hal-hal yang menurut ketentuan Anggaran Dasar, Anggaran Rumah Tangga dan/atau Keputusan-Keputusan lain yang telah ditetapkan oleh organisasi Ikatan Notaris Indonesia tidak boleh dilakukan oleh anggota."

\section{Kesalahan Notaris}

Kesalahan dapat timbul karena dua hal yaitu kelalaian (culpa) dan kesengajaan (dollus).

${ }^{8}$ Kesengajaan adalah perbuatan yang dilakukan dengan dikehendaki. Untuk terjadinya kesengajaan tidak diperlukan adanya maksud untuk menimbulkan kerugian kepada orang lain. Kebanyakan kesalahan yang dilakukan oleh seorang Notaris memang tidak ada unsur kesengajaan. Namun sebagai pejabat negara hendaknya seorang Notaris benarbenar memahami UUJN dan Kode Etik Notaris. Seperti halnya diatur dalam pasal 4 angka 3 UUJN bahwa notaris tidak diperkenankan untuk melakukan promosi ataupun publikasi diri melalui media cetak maupun elektronik. Hal ini berarti notaris tidak diperkenankan untuk melakukan publikasi meskipun hanya menuliskan jabatannya sebagai notaris di sosial media.

\section{Hambatan dalam penegakan Kode Etik Notaris}

Notaris seringkali meremehkan Kode Etik Notaris yang dibuat oleh Ikatan Notaris Indonesia karena tidak dibuat oleh pemerintah Republik Indonesia. Selain itu INI juga dianggap kurang tegas dalam menjatuhkan sanksi kepada notaris yang melanggar Kode Etik. Faktor lainnya karena Dewan Kehormatan tidak tanggap dalam menangani

\footnotetext{
${ }^{8}$ Putu Adi Purnomo Djingga Wijaya, Tanggung Jawab Notaris Terhadap Kesalahan Dalam Pembuatan Akta yang Dilakukan Oleh Notaris Penggantinya, hlm 115.
} 


\section{Jurnal Panorama Hukum}

pelanggara Kode Etik Notaris. Pendapat serupa disampaikan oleh Sidharta Pohan Prastowo dalam bukunya yang berjudul "Standar Disiplin Profesi Hukum". Hal lain juga dianggap menjadi penghambat dalam penegakan Kode Etik Notaris adalah saling melindungi antar rekan sejawat yang tidak dilakukan nya dalam proporsi yang benar dan tepat.

Mengingat semakin maraknya pelanggaran Kode Etik oleh Notaris, hal ini bisa mengakibatkan menurunnya kepercayaan masyarakat pada profesi Notaris yang selama ini dianggap terhormat dan mulia. Maka organisasi profesi notaris (INI) harus segera berbenah diri untuk menghindari menurunnya kepercayaan masyarakat awam pada profesi Notaris.

\section{Kesimpulan}

Dari hasil penelitian dan tinjauan dari berbagai sumber, dapat diambil kesimpulan bahwa Hukum yang mengatur tentang hal-hal yang tidak boleh dilakukan seorang Notaris sudah jelas mengatur hal yang berkaitan dengan promosi jasa notaris. Hanya saja Dewan Kehormatan dari organisasi profesi INI yang dalam hal ini berperan dalam penegakan Kode Etik Notaris kurang tegas dalam menindaklanjuti pelanggaran-pelanggaran yang dilakukan oleh Notaris mengingat kebanyakan Dewan Kehormatan adalah rekan-rekan dari Notaris itu sendiri.

\section{Daftar Pustaka}

Adjie, Habib, (2009), Hukum Notaris Indonesia (Tafsir Tematik Terhadap UU No.30 Tahun 2004 Tentang Jabatan Notaris), Bandung, Refika Aditama.

Raharjo, Satjipto, (1983), Masalah Penegakan Hukum, Sinar Baru, Bandung

Yovita A. Mangesti dan Bernard L. Tanya, (2014), Moralitas Hukum, Yogyakarta: Genta Publishing

Peraturan Per-Undang-undangan

Kode Etik Notaris (Ikatan Notaris Indonesia / I.N.I)

Undang-Undang Nomor 2 Tahun 2014 tentang Perubahan Undang-Undang Nomor 30 Tahun 2004 tentang Jabatan Notaris

$\underline{\text { Jurnal }}$ 
Ferdiansyah Putra, Perlindungan Hukum Terhadap Para Pihak Yang Dirugikan Atas Penyuluhan Hukum Oleh Notaris

Riyan Saputra, Penegakan Hukum Terhadap Notaris Yang Mempromosikan Diri Melalui Media Sosial

Stephanie, Peranan Ikatan Notaris Indonesia (I.N.I) Terhadap Pengawasan Notaris Dalam Pelaksanaan Tugas Jabatan Notaris Di Provinsi Dki Jakarta

Putu Adi Purnomo Djingga Wijaya, Tanggung Jawab Notaris Terhadap Kesalahan Dalam Pembuatan Akta yang Dilakukan Oleh Notaris Penggantinya 